\title{
The key enablers, techniques and benefits of managing stakeholders within BIM supported projects
}

\author{
Sukhtaj Singh \\ University of Wolverhampton \\ https://orcid.org/0000-0002-3368-7182 \\ Ezekiel Chinyio \\ Reader in Construction Management, University of Wolverhampton \\ https://orcid.org/0000-0001-8448-5671 \\ Subashini Suresh \\ Reader and Director for Postgraduate Research Programme, University of \\ Wolverhampton \\ https://orcid.org/ 0000-0001-5266-128X
}

Published in Journal of Engineering, Design and Technology

ISSN: 1726-0531 DOI: TBA

Please cite as: Singh, S.; Chinyio, E. \& Suresh, S. (2022). The key enablers, techniques and benefits of managing stakeholders within BIM supported projects. Journal of Engineering, Design and Technology, [published Ahead of Print] DOI: TBA

Deposit License: [This article is (C) Emerald Publishing Limited and permission has been granted for this version to appear here (https://wlv.openrepository.com/wlv/). Emerald does not grant permission for this article to be further copied/distributed or hosted elsewhere without express permission from Emerald Publishing Limited.]

\section{Acknowledgements}

The authors would like to thank the University of Wolverhampton for granting a $\mathrm{PhD}$ studentship to carry out the research that informed this article. 


\title{
The key enablers, techniques and benefits of managing stakeholders within BIM supported projects
}

\author{
Abstract \\ Purpose \\ Project managers still face challenges with managing stakeholders. Using BIM \\ has further increased these challenges. Meanwhile, there is a paucity of research \\ specifically focusing on the techniques, which organisations are adopting to \\ manage stakeholders within BIM-implemented projects and the associated \\ benefits, which they can reap. Thus, this research aimed to identify the key \\ techniques, enablers and benefits of managing stakeholders within BIM- \\ implemented projects. \\ Methodology
}

An exploratory approach was adopted due to the paucity of the variables on the topic. In total, 23 semi-structured interviews were conducted in the UK through purposive and snowball sampling. The data were analysed using content analysis and the 'NVivo 11 Pro' software.

Findings

Two key techniques and two enablers required to manage stakeholders within BIM-implemented projects were identified. Nine benefits of managing stakeholders were identified which split into interim and eventual benefits.

Originality

This paper provides a richer understanding of the enablers and techniques, which organisations should focus on while strategizing for minimum resistance from stakeholders in their BIM implemented projects.

Keywords: benefits; BIM; construction projects; enablers; stakeholder management; techniques 


\section{Introduction and theoretical perspective}

The construction sector is ever adopting emerging innovative technologies such as Building Information Modelling (BIM), artificial intelligence (AI), machine learning, augmented reality (AR), virtual reality (VR), construction robotics and drones, etc. These technologies have tremendous potential for accelerating the transition of the construction industry from a traditional to well-advanced industry (Yang et al., 2019). BIM, the subject of this article, incorporates many dimensions for data integration and information delivery and its use is changing the existing modus operandi of the construction industry (Sheikhkhoshkar et al., 2019).

The implementation of BIM has demanded a radical change in the working practices of project stakeholders (Lindblad and Vass, 2015) because it brought new and complex activities to an already complex process of construction project management, affected the role of project stakeholders and generated new risks and threats in diverse areas (Liu et al., 2017; Okakpu et al., 2020). Furthermore, construction projects are becoming much more complex in social and technical perspectives, which has escalated the complications in the relationships between various stakeholders in the industry (Wang et al., 2020). He et al. (2017) identified that during the construction of the Shanghai Tower, the technical aspect of BIM was not an inhibitor; rather the difficulty in its implementation concerned the coordination of eight different BIM teams that came from diverse backgrounds. This experience reinforces the need for improving the management of stakeholders in BIM-implementation projects. Indeed, BIM has been researched significantly especially in its technical domain, i.e., mobile and cloud computing, laser scanning, augmented reality, safety rules, automated code checking and automated model generation, etc. However, the non-technical aspect of BIM remains hugely under-researched (Turk, 2020). 
There is abundant literature on the challenges of implementing BIM (e.g., Khoshfetrat et al., 2020; Ghaffarianhoseini et al., 2017). Furthermore, many studies have been conducted to investigate the factors facilitating the adoption of BIM; for instance, factors facilitating the adoption of BIM on refurbishment projects (Okakpu et al., 2020), factors facilitating the adoption of BIM in developing countries (Ahuja et al., 2020), factors affecting the implementation of BIM by SMEs (Awwad et al., 2020), conducive measures for increasing the uptake of BIM in building services engineering (BSE) (Chiu and Lai, 2020) and factors to reduce challenges in BIM projects (Blay et al., 2019). However, there is a paucity of literature about the techniques and benefits of managing stakeholders within BIM-implemented projects and any challenges in this regard. For instance, improved stakeholder and public engagement is one of the benefits to the BSE group of adopting BIM; ranking no. 2 to them in contrast with the non-BSE group that ranked it no. 6 (Chiu and Lai, 2020). Project managers still face challenges of managing stakeholders in the course of project management (Huemann et al., 2016). Singh et al. (2017) catalogued 22 critical success factors (CSFs) for managing stakeholders with the top five (in descending order) being: communicating with and engaging stakeholders properly and frequently; using a formalised process for identifying stakeholders; keeping and promoting a good relationship; exploring stakeholders' needs and constraints to projects; and early involvement of key project participants.

Several authors have identified the techniques for managing stakeholders. Chinyio and Akintoye (2008) recommended making bespoke communication strategies that should depend on the power, interest and urgency of the stakeholders. Lehtinen and Aaltonen (2020) recommended that organisations should adopt several different ways of disseminating information about the project to external stakeholders; e.g. using 
websites, leaflets, bulletins, communication campaign and organised big media events.

Furthermore, workshops can be organised to engage with external stakeholders at e.g., site visit events. Meetings can be operationalised in different ways for aligning both project and stakeholders' objectives. In this regard, project managers can arrange weekly meetings with project team members and contractors to inform them about their project's progress; socialise more with other team members; raise any issues arising with the project owner during meetings; and take part in community meetings, activities and ceremonies (Wembe, 2020). Table I provides a compilation of the enablers and techniques which can be used for managing stakeholders.

Table I: The enablers * and techniques of managing stakeholders

\begin{tabular}{|l|l|}
\hline Techniques and enablers of managing stakeholders & References** \\
\hline $\begin{array}{l}\text { Different ways of disseminating information, such as websites, } \\
\text { leaflets, bulletins, letters, memos, faxes, minutes of meeting, etc. } \\
\text { depending on the priority of stakeholders }\end{array}$ & $1,2,3,4,6$ \\
\hline Use of trade-offs & 3 \\
\hline Use of incentives & 3 \\
\hline Use of concessions & 3 \\
\hline Use of workshops & $1,3,5$ \\
\hline Use of negotiation & 3 \\
\hline Setting dedicated communication teams & 1 \\
\hline $\begin{array}{l}\text { Dividing tasks and responsibilities between internal stakeholders } \\
\text { for managing external stakeholders }\end{array}$ & 1 \\
\hline $\begin{array}{l}\text { Setting goals for and measuring external stakeholder } \\
\text { engagement }\end{array}$ & 1 \\
\hline $\begin{array}{l}\text { Flexible roles and responsibilities to internal stakeholders for } \\
\text { managing external stakeholders }\end{array}$ & 1 \\
\hline $\begin{array}{l}\text { Implementing feedback system to capture feedback from } \\
\text { external stakeholders }\end{array}$ & 1 \\
\hline $\begin{array}{l}\text { Introducing reward and punishment system for internal } \\
\text { stakeholders depending on the result of managing external } \\
\text { stakeholders }\end{array}$ & 1 \\
\hline Opportunities to participate in various initiatives & 4 \\
\hline Supplier diversification & 4 \\
\hline $\begin{array}{l}\text { Meetings: with project owners, project team members, } \\
\text { contractors, stakeholders and at community events, activities } \\
\text { and ceremonies }\end{array}$ & $1,3,5$ \\
\hline
\end{tabular}




\begin{tabular}{|l|l|}
\hline $\begin{array}{l}\text { Communication: preferably face-to-face between project } \\
\text { manager and team members, contractors and suppliers }\end{array}$ & 5 \\
\hline $\begin{array}{l}\text { Engaging project team members in problem solving, reviewing } \\
\text { new requirements and lessons learnt }\end{array}$ & 5 \\
\hline $\begin{array}{l}\text { After identifying stakeholders, approaching them individually } \\
\text { rather than a meeting }\end{array}$ & 6 \\
\hline Privacy: e.g. liaising with stakeholders individually & 6 \\
\hline
\end{tabular}

* Enablers are shown in italics and techniques in a normal text.

** Source: 1 = Lehtinen and Aaltonen (2020); $2=$ Lehtinen et al. (2019); $3=$ Chinyio and Akintoye (2008); $4=$ Kolk and Pinkse (2006); $5=$ Wembe (2020); $6=$ Wembe (2021)

Schembri et al. (2019) and Tantalo and Priem (2016) identified the benefits of managing stakeholders, which include: greater commitment of stakeholders to an organisation's objectives; increased legitimacy of an organisation; more potential for value creation; more competitive advantage; increased trust in organisation-stakeholder relationships; and increased reciprocity in these relationships. However, these benefits have not been researched in the context of the construction industry. Therefore, this study explored this aspect in the construction sector, as well as the enablers and techniques of managing stakeholders. There is limited literature related to the management aspect of implementing BIM especially the techniques to be adopted and benefits, which can be gained from managing stakeholders; thus, there is a need to ascertain how this is experienced empirically. To address this need, this research aimed to explore the enablers, techniques and benefits of managing stakeholders by establishing the following research objectives in the context of BIM-implemented projects:

To explore the key techniques organisations are using for managing stakeholders effectively.

To study the key enablers and benefits of managing stakeholders effectively. In order to achieve these objectives, the research adopted an exploratory interpretative qualitative approach, as described below. 


\section{Methodology}

Research methodology involves analysing the assumptions, principles and processes adopted for an inquiry (Schwandt, 2009). The inductive approach is appropriate when a topic is new and there is limited literature (Saunders et al., 2019). This was the case in this study hence the inductive approach was adopted which led to a qualitative research.

Qualitative research enables the understanding of complex phenomena by helping researchers to understand the behaviours or cognitions of people and organisations, as well as their beliefs, rituals, values and emotions (Ograjensek, 2016). It is a useful approach if a researcher is looking for insights into human experiences (Erlingsson and Brysiewicz, 2017). An exploratory approach was used as it is viable when the variables and theory base are not known (Creswell, 2014).

The purposive and snowball sampling techniques were adopted. Purposive sampling places primary emphasis on data saturation, i.e., data collection is continued till no new substantive information is emerging (Etikan et al., 2016). Primary data was collected directly from BIM-practitioners in the UK through semi-structured interviews. The data collection was continued until it reached saturation point, which was decided on the basis of data saturation theory as explained by Francis et al. (2010). In total, 23 interviews were conducted. This assisted in creating a unique sample that captured the problem exhaustively. The research sample included participants from diverse backgrounds with experience ranging from 1 year to more than 40 years (refer to Table II).

The interviews were recorded, transcribed and evaluated by using content analysis with the aid of the NVivo 11 Pro software. The trustworthiness criteria for qualitative content analysis comprises of credibility, dependability and transferability 
(Graneheim and Lundman, 2004). Given the qualitative nature of the data, the authors chose to adopt qualitative content criteria over quantitative content analysis criteria.

Credibility demands researchers to explicitly state and justify their sampling and data collection method and, show the ways to judge similarity and differences between different categories (developed from the data analysis). The authors proposed two ways to do this: by showing quotes from research participants, and by discussing categories (results) developed with experts, colleagues or participants. In this article, some quotes from some of the research participants are cited and discussed.

The adoption of semi-structured interviews was sufficient to address the element of dependability because it allowed the interviewer to ask all the interviewees questions in the same order. To address transferability, the interviewer provided the interviewees a clear description of the research context, sampling, characteristics of interviewees, and data collection and analysis methods. This approach enhances the transferability of results (Okapku et al., 2020). It is argued that the findings are transferable to the construction industry of other nations that are lagging behind the UK in terms of BIM implementation. However, it is the reader or user of the findings who will ultimately decide whether the findings are transferable to their own settings or not (Graneheim and Lundman, 2004).

\section{Information about the interviewees}

Table II shows the background information of the research participants, including their designation, experience and the duration their organisation has been using BIM.

Table II: Profile of research participants

\begin{tabular}{|l|l|l|l|l|l|}
\hline $\begin{array}{l}\text { Intervie } \\
\text { wee No. }\end{array}$ & $\begin{array}{l}\text { Experien } \\
\text { ce } \\
\text { (years) }\end{array}$ & $\begin{array}{l}\text { Role } \\
\text { Designation }\end{array}$ & $\begin{array}{l}\text { Organisatio } \\
\text { n using BIM } \\
\text { (years) }\end{array}$ & $\begin{array}{l}\text { Organisatio } \\
\text { n's BIM } \\
\text { maturity } \\
\text { level }\end{array}$ & Organisation type \\
\hline
\end{tabular}




\begin{tabular}{|c|c|c|c|c|c|}
\hline 1 & 1 & $\begin{array}{l}\text { BIM } \\
\text { coordinator }\end{array}$ & 2 years & $\begin{array}{l}\text { Between } 1 \\
\text { and } 2\end{array}$ & $\begin{array}{l}\text { Main contractor } \\
\text { specialising in road } \\
\text { infrastructure }\end{array}$ \\
\hline 2 & 17 & $\begin{array}{l}\text { Divisional } \\
\text { engineering } \\
\text { manager }\end{array}$ & 10 years & Level 2 & $\begin{array}{l}\text { Main contractor } \\
\text { specialising in } \\
\text { infrastructure } \\
\text { (geotechnical) }\end{array}$ \\
\hline 3 & $30+$ & $\begin{array}{l}\text { Design } \\
\text { manager }\end{array}$ & $\begin{array}{l}2 \text { years but } \\
\text { has been } \\
\text { using for } 4 \\
\text { years }\end{array}$ & $\begin{array}{l}\text { Between } 1 \\
\text { and } 2\end{array}$ & $\begin{array}{l}\text { Main contractor } \\
\text { specialising in rail } \\
\text { infrastructure }\end{array}$ \\
\hline 4 & 38 & $\begin{array}{l}\text { Head of } \\
\text { planning and } \\
\text { digital } \\
\text { construction }\end{array}$ & 6 years & Level 2 & $\begin{array}{l}\text { Main contractor } \\
\text { specialising in } \\
\text { infrastructure } \\
\text { (geotechnical) }\end{array}$ \\
\hline 5 & 10 & BIM manager & 6 years & Level 2 & $\begin{array}{l}\text { Main contractor } \\
\text { specialising in } \\
\text { infrastructure } \\
\text { (academic, buildings, } \\
\text { prisons) }\end{array}$ \\
\hline 6 & $20+$ & $\begin{array}{l}\text { Project } \\
\text { manager }\end{array}$ & 6 years & Level 2 & $\begin{array}{l}\text { Main contractor } \\
\text { specialising in } \\
\text { infrastructure } \\
\text { (academic, buildings, } \\
\text { prisons) }\end{array}$ \\
\hline 7 & 32 & $\begin{array}{l}\text { Commercial } \\
\text { manager }\end{array}$ & 6 years & Level 2 & $\begin{array}{l}\text { Main contractor } \\
\text { specialising in } \\
\text { infrastructure } \\
\text { (academic, buildings) }\end{array}$ \\
\hline 8 & 18 & $\begin{array}{l}\text { Design } \\
\text { manager }\end{array}$ & 6 years & Level 2 & $\begin{array}{l}\text { Main contractor } \\
\text { specialising in } \\
\text { infrastructure } \\
\text { (academic, buildings) }\end{array}$ \\
\hline 9 & 19 & $\begin{array}{l}\text { BIM } \\
\text { Consultant }\end{array}$ & $5+$ years & $\begin{array}{l}\text { It depends } \\
\text { on the role }\end{array}$ & BIM consultant \\
\hline 10 & 20 & $\begin{array}{l}\text { Digital } \\
\text { manager }\end{array}$ & 3 years & Level 2 & $\begin{array}{l}\text { Main contractor } \\
\text { (buildings) }\end{array}$ \\
\hline 11 & 20 & CEO & 20 years & Level 2 & Software (producer) \\
\hline 12 & $40+$ & CEO & $15+$ years & Level 2 & BIM consultant \\
\hline 13 & $20+$ & $\begin{array}{l}\text { Assistant } \\
\text { director }\end{array}$ & 2 years & Level 1 & Client \\
\hline 14 & 15 & $\begin{array}{l}\text { Digital } \\
\text { manager }\end{array}$ & $10+$ years & Level 2 & $\begin{array}{l}\text { Designer } \\
\text { (Engineering) }\end{array}$ \\
\hline 15 & 2 & $\begin{array}{l}\text { Stakeholders } \\
\text { liaise } \\
\text { assistant }\end{array}$ & 5 years & Level 2 & $\begin{array}{l}\text { Main contractor } \\
\text { (rails) }\end{array}$ \\
\hline
\end{tabular}




\begin{tabular}{|l|l|l|l|l|l|}
\hline 16 & 12 & $\begin{array}{l}\text { Digital } \\
\text { manager }\end{array}$ & 5 years & Level 2 & $\begin{array}{l}\text { Main contractor } \\
\text { (buildings) }\end{array}$ \\
\hline 17 & 11 & BIM Manager & $10+$ years & Level 2 & $\begin{array}{l}\text { Main contractor } \\
\text { (academic, buildings) }\end{array}$ \\
\hline 18 & 12 & $\begin{array}{l}\text { Project } \\
\text { manager }\end{array}$ & 2 years & Level 1 & Client \\
\hline 19 & 2 & $\begin{array}{l}\text { BIM } \\
\text { coordinator }\end{array}$ & 2 years & Level 2 & $\begin{array}{l}\text { Main contractor } \\
\text { (roads } \\
\text { infrastructure) }\end{array}$ \\
\hline 20 & 6 & $\begin{array}{l}\text { BIM-GIS } \\
\text { Coordinator }\end{array}$ & 2 years & Level 2 & $\begin{array}{l}\text { Main contractor } \\
\text { (roads } \\
\text { infrastructure) }\end{array}$ \\
\hline 21 & 8 & BIM manager & 5 years & Level 2 & $\begin{array}{l}\text { Main contractor } \\
\text { (roads } \\
\text { infrastructure) }\end{array}$ \\
\hline 22 & 9 & BIM manager & 3 years & Level 2 & $\begin{array}{l}\text { Main contractor } \\
\text { (roads } \\
\text { infrastructure) }\end{array}$ \\
\hline 23 & $20+$ & BIM manager & 8 years & Level 2 & $\begin{array}{l}\text { Main contractor } \\
\text { with design } \\
\text { functions (roads } \\
\text { Infrastructure) }\end{array}$ \\
\hline
\end{tabular}

Table II shows that seven interviewees $(30 \%)$ had more than 20 years of experience, five participants (22\%) had between 16 to 20 years; and four interviewees (17\%) had between 11 to 15 years of experience. Only three interviewees $(13 \%)$ had less than five years of experience; but it was crucial to capture their views also because their organisations' BIM maturity level was above 1. Interviewee no. 1 in particular had only one year of experience, but her views were considered in the analysis as her organisation's BIM maturity was equivalent to that of interviewee no. 3's who has more than 30 years of experience. Also considered was interviewee no. 13 whose organisation's BIM maturity level was 1 but this individual had 20+ years of experience.

Table II shows that most of the interviewees (circa 70\%) belonged to main contractors' organisations. Two interviewees (9\%) were clients, another two were BIM 
consultants, and one interviewee each was: designer, software organisation and designer company that carries out some contractor functions.

\section{Results and discussion}

\subsection{The key techniques and enablers of managing stakeholders}

The interviewees were asked to explain the key techniques of managing stakeholders within-BIM implemented projects. Table III shows the themes generated from the information they provided; these are discussed in the following sub-sections.

Table III: Key techniques and enablers of managing stakeholders on BIM implemented projects

\begin{tabular}{|l|l|l|}
\hline Key theme & Percentage $(\mathbf{n}=\mathbf{2 3})$ & Technique/enabler \\
\hline The learning experience & $87 \%(20)$ & Enabler \\
\hline $\begin{array}{l}\text { Holding (face-to-face) } \\
\text { meetings }\end{array}$ & $83 \%(19)$ & Technique \\
\hline $\begin{array}{l}\text { Usage of online tools for } \\
\text { collaboration }\end{array}$ & $78 \%(18)$ & Technique \\
\hline $\begin{array}{l}\text { The sharing and learning } \\
\text { environment }\end{array}$ & $78 \%(18)$ & Enabler \\
\hline
\end{tabular}

\subsubsection{The learning experience}

The implementation of new systematic routines and working practices often requires underpinning knowledge, which in turn may warrant prior training of workers (Mellado and Lou, 2020). Therefore, education and training are important and should be emphasised when new things like BIM are being implemented. BIM which is relatively new has its own complexities in terms of its processes, which makes its projects to be different from traditional construction in terms of practices. Education about the BIM process is fundamental in managing projects generally and stakeholders particularly. Inadequate understanding of the BIM concept is the most critical challenge in the implementation of the concept. To overcome this challenge, education is essential which can be affected through on-the-job training. Chiu and Lai (2020) identified 
training as one of the key factors to increase the uptake of BIM in BSE.

In this study, $87 \%$ (20 of 23 ) of the interviewees agreed that education and training of project teams are very crucial for managing them successfully. Concerning education, interviewee no. 5 noted that:

"You also have to educate the team internally because they need to understand what the deliverables are going forward".

Regarding training, interviewee no. 17 noted that:

"We will hold training sessions. At the start of a project, we will have training sessions with the client, our design team, our supply chain, and also our internal team because they're not always the best in a common data environment".

These express views indicate that education and training are both necessary for managing stakeholders within BIM implemented projects. Education is required to make them understand the various constituents and fundamentals of BIM processes, and training is necessary for implementing BIM appropriately. This aligns with the findings of Awwad et al. (2020) who identified awareness and training on the BIM process as most influential factors affecting the skills, ability and mind-set of stakeholders who adopt BIM.

An individual's total learning experience is composed of both education and training. With increasing complexities in organisations, both are necessary for improving the potentials of employees (Masadeh, 2012).

Akins and Griffin (1999) argued that individuals should be trained in developing only skills relevant to their job because it is difficult for people to learn all the aspects of business knowledge. Accordingly, interviewee no. 21 noted that: 
“There's nothing more disengaging than getting 40 people in a meeting room for a full-day session when $80 \%$ of it doesn't relate to them."

\subsubsection{Holding (face-to-face) meetings}

In this study, $83 \%$ of the interviewees (19 of 23 ) preferred meetings (face-to-face communication) as a key technique to manage stakeholders. This finding suggests that (face-to-face) communication is a preferable means of resolving issues. Along with this, reducing the volume of emails was also emphasised by interviewees.

Ferreira and Ramos (2014) and Paul et al. (2016) argued that though technology has overcome the barriers of time and space in this modern era, communicating face-toface is still a better way than all types of computer-related communication. Bostrom et al. (1993) mentioned two types of outcomes from meetings, i.e., task-related outcomes and relational outcomes. Task-related outcomes mean individuals meet to e.g.: accomplish some tasks such as developing a plan, make a decision to share information, solve a problem, resolve a dispute and to negotiate a contract.

"We do it mainly through meetings, and then view the model at the meetings. So, I think that's another benefit of the 3D model; everyone can sit in the same room and get a perspective of what's being discussed”. (Interviewee no. 7)

Liu et al. (2017) argued that past non-BIM experience could only assist in successfully accomplishing traditional projects. It will not necessarily assist in developing the collaboration that is required for accomplishing BIM-implemented projects. Therefore, project stakeholders should organise more formal meetings than traditional ways of collaboration to enhance their understanding of BIM activities. 
A relational outcome means that a meeting develops or strengthens a relationship between different people. This type of meeting generates emotions, which in turn creates feelings, which affects the development and quality of the relationship between attendees. These meetings aim to encourage effective collaboration. Negative energy in these types of meetings is not avoided but is redirected towards a positive direction (Bostrom et al., 1993). These types of meetings should be promoted in BIMimplemented projects.

Interviewee no. 21 recommended the organisation of BIM sessions with the client at the outset of the project. This interviewee argued that these types of sessions help them to know more about the needs of their client and stimulate trust between both the parties. Interviewee no. 2 mentioned that in BIM implemented projects, the first step they take is to organise a BIM meeting involving the project teams. There, they make project teams discuss with one another, from the very basics to their understanding of BIM in the context of their project. They call this meeting a 'BIM Awareness Session.' It is followed by a 'BIM Goals Session'. In this meeting, they discuss the key risks involved in a particular project; processes to reduce those risks; if that project requires specific BIM tools; the skills of the workforce related to those tools, special training of staff to operate tools, if special hardware is required, if tools will affect the selection of their supply chain, among others. Alreshidi et al. (2017) identified in their research that project stakeholders organised regular face-to-face BIM meetings to discuss their progress and to receive specific updates on interim milestones and goals, which are used for tracking the achievement of project objectives. Wembe (2020) also identified high face-to-face communication of project manager with project team members and contractors as a critical factor for managing them even though the research was 
conducted in a non-BIM environment. Where the project team was located remotely, stakeholders can use Skype or similar technology for virtual face-to-face interactions.

Use of Emails

Emails are useful for communication, but some people do not check their emails often. Messages through emails can also be subject to misinterpretation. The data analysis indicated that people should encourage informal talk instead of sending emails frequently. Interviewee no. 23 noted that:

"I can send you lots and lots of communication, and whether you understand it and whether you read it back to me is completely different. So, people think of writing emails as if they are communicating. They are not. They are broadcasting".

Interviewee no. 10 corroborated that key communication is via meetings and conversation, i.e.:

"Face-to-face talking removes emails is what I would say, because it sounds strange what the problem with emails is that everyone gets thousands of them every day and they never look at them".

Interviewees no. 21 argued that meetings should be held frequently in BIM implemented projects. Liu et al. (2017) on their part argued for the encouragement of informal communication among project stakeholders in a BIM environment. However, considering the segregated nature of the construction industry, it is acknowledged that it is not always possible to arrange face-to-face talks. Lee and Panteli (2011) noted that face-to-face meetings can be expensive, be time-consuming and difficult to arrange 
(especially when team members are fragmentarily located). Furthermore, emails act as a repository of exchanged communication that can be referred to when required. The authors identified in their research that project participants used emails as proof when accusing other participants of causing problems for the project.

Lee and Panteli (2011) identified in their research that when the discussions are related to complex processes or products, emails should be complemented with face-toface meetings and other computer-mediated communication methods to improve communication effectiveness. If only email is chosen as a communication medium for complex processes, it may lead to conflicts among project stakeholders. Group emails should include only those project participants who need to know the information being relayed.

This study concludes that both formal and informal communication should be encouraged on BIM-implemented projects. When informal communication involves sensitive information, it can be backed up with email where critical points of discussion are summarised.

\subsubsection{Usage of online collaboration tools}

Collaboration stimulates information sharing, reduces conflicts and improves the delivery of the client's objectives (NBS Construction Technology Report 2019). Within BIM-implemented projects, a common data environment (CDE) provides an online platform for collaboration by enabling the sharing of geometric information, registers, schedules, contracts, reports and model information. It gathers all project stakeholders' information into a virtual space. This shared information is accessible to all project team members (Comiskey, 2017). In this study, 78\% (18 of 23) of the interviewees agreed that they are using online collaboration tools (the CDE software) for sharing information, which has reduced disputes among them. Interviewee no. 2 noted: 
"[A] common data environment is a fantastic place for data housing. The key issue we face on a project is to find the right information when we need it quickly. I think CDE comes in handy at that time. Information is right and up to date. We can send messages to concerned persons straight away if there are any concerns".

Project stakeholders also share screenshots of BIM models to discuss concerns with each other. This assists both parties (the person who has a concern and the person with whom he/she has that concern) to understand the issue easily. This quick interaction was previously not possible in traditional projects where 2D drawings were used. As interviewee no. 3 noted:

"I often see my colleagues sharing screenshots of models for any concerns. Yeah, they often do that. Just a little tiny thing makes life so much easier. What I have seen is they often get quick replies back".

Okakpu et al. (2020) recommended using BIM for information sharing and collaboration. Alreshidi et al. (2017) identified that BIM practitioners shared BIM model screenshots with other team members to resolve the issues. BIM practitioners used emails to communicate. However, findings of this study indicate that using data platforms rather than emails was more effective for communication, as it tracks who, when and why a decision was made in a better way.

\subsubsection{The sharing and learning environment}

In this study, $78 \%$ of the interviewees (18 of 23 ) agreed that organisations should create a sharing and learning environment, which is essential to diffuse innovation in an 
organisation. When employees collaborate to share their experiences, knowledge, vision and skills, organisational learning takes place. Traditional mentoring and peer mentoring are among the best ways to transfer knowledge to novice users and colleagues because change at personal level can be influenced best by colleagues, family and friends (Peansupap and Walker, 2005). Marsh (2017) researched three construction organisations that implemented mentoring programmes and identified that all had massive success in achieving their goals. The key reason was that the top management of these three organisations were fully involved in supporting and monitoring the mentoring programmes, both at a group and regional level. Cost savings and improvements in business processes were evident in all three. To support workers, Interviewee no. 23 opined that:

"Help them in their tasks, find out their worries, guide them. Usually, I have seen people are too shy to ask. Make them feel comfortable so that they can come to you".

Interviewee no. 3 indicated that they still contract with members of their supply chain that have no BIM capability. They assist them in learning and delivering what is required from them contractually.

Awwad et al. (2020) categorised the critical success factors (CSFs) of BIM implementation into four categories: human, organisational, process and external. One success factor identified in this study, i.e., 'the learning experience' fits into the 'human' category. The other factors established in this study do not fit into any of the categories mentioned by Awwad et al. (2020). The possible reason can be that the research conducted by Awwad et al. (2020) concerned the attainment of BIM maturity, whereas this research concentrated on stakeholder management. Furthermore, none of 
the CSFs (refer to section 1) catalogued by Singh et al. (2017) was mentioned by the interviewees.

\subsection{Benefits of managing stakeholders}

The research question, 'what are the key benefits of managing stakeholders within BIMimplemented projects?' was put to the interviewees. Table IV shows the findings.

During data analysis, the benefits were divided into two categories, i.e., interim benefits and eventual benefits. The interim benefits eventually lead to the eventual benefits.

Figure 1 shows both interim and eventual benefits, which are discussed in the subsequent paragraphs.

Table IV: Key benefits of managing stakeholders on BIM projects

\begin{tabular}{|l|l|}
\hline Key benefits & Percentage (N = 23) of respondents \\
\hline Clear understanding of the end result & $87 \%(20)$ \\
\hline Unanticipated problems can be avoided & $83 \%(19)$ \\
\hline Good quality information & $83 \%(19)$ \\
\hline Improved cost savings & $83 \%(19)$ \\
\hline Time savings & $83 \%(19)$ \\
\hline Repeat business & $78 \%(18)$ \\
\hline $\begin{array}{l}\text { Better understanding of the project } \\
\text { workflow }\end{array}$ & $74 \%(17)$ \\
\hline Better communication & $70 \%(16)$ \\
\hline Improved quality & $70 \%(16)$ \\
\hline
\end{tabular}

\section{Interim benefits of stakeholder management \\ Unanticipated problems can be avoided \\ Clearer understanding of the end result \\ Better communication \\ Good quality information \\ Better understanding of the project workflow}

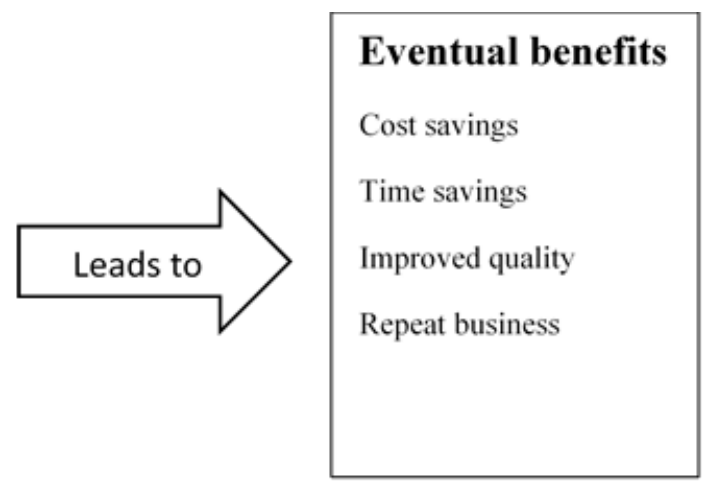

Figure 1: Interim benefits and eventual benefits of managing stakeholders 


\subsubsection{Clearer understanding of the end result}

3D models enable to understand the end-product easily. This can be extremely beneficial especially for developing trustworthy relationships with a client. One of the interviewees, no. 16, explained that it has happened with them several times that what they delivered as an end product was not what the client wanted exactly. This incident concerned a non-BIM project. It was a college project which was almost over, and colouring was going on. The client realised that it was not the colour scheme they wanted. Moreover, the client objected on the use of several materials. So, the client made them to change some of the colour scheme and materials. This interviewee no. 16 explained how a BIM model could have showed them how the product would look like, and they could have avoided this scenario with the client. According to him:

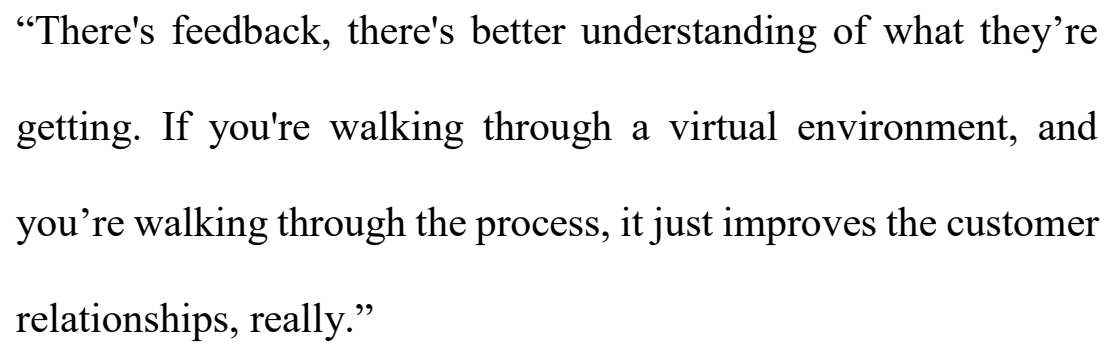

Another interviewee narrated an anecdote of a school project when the client argued about the less space for students in the playground. In the beginning, this client could not visualise from 2D drawings that there would not be enough space for all children to gather simultaneously and comfortably for morning prayer. The client realised the problem when construction was going on. The interviewee argued that situations like these could be prevented with the help of 3D models because they provide a better view of the situation; thus, contributing to improved relationships which can facilitate getting repeat business from a client. $87 \%$ of the interviewees concurred with this opinion. 


\subsubsection{Unanticipated problems can be avoided}

3D, 4D and 5D aspects of BIM can assist in detecting various kinds of unanticipated issues in advance. $83 \%$ of the interviewees agreed that unanticipated problems can affect the cost and schedule of a project. So, identifying problems earlier can help improve the efficiency of a project. For instance, 3D BIM can assist in avoiding problems related to design. As 4D BIM can assist in visualising the sequence of a construction process, it can assist immensely in detecting problems related to site logistics, site set-up and scaffolding, among others. 5D BIM can show clients how the changes in design can impact on cost and programme of the project. The interviewee no. 7 narrated an incident which happened on one of their projects:

"A simple example the other day is we were going through the steel frame, but we got to a section in the building, and we picked up that there were square hollow sections, whereas we thought, traditionally, those members would be I-beams and the architect had asked for those for aesthetic reasons. They weren't necessarily a structurally designed element. Long before we'd even got to procuring the steel, we could go back to the consultants and say, "Why do you want square hollow sections?" "They're more expensive. I don't think we would have picked that up necessarily, with the time we've usually got."

Detecting clashes late onsite sometimes limits the options for finding effective solutions and any consequent rework can increase the health and safety risks. Furthermore, the effect on other activities and wastage of time can lead to litigation among stakeholders. Thus, by making stakeholders work collaboratively with the aid of technology, diverse 
types of unanticipated issues can be avoided. The identification of diverse types of unanticipated issues in advance contributes to reducing uncertainty, which eventually contributes to reducing the risks of a project and increasing efficiency.

\subsubsection{Good quality information}

The frequency of litigation on construction contracts due to incorrect or late information has increased during the last 40 years (NBS National BIM Report 2015). $83 \%$ of the interviewees agreed that late or incorrect information is the prime reason of conflict among stakeholders such as architects, QS, engineers and the supply chain. The interviewee no. 7 stated that due to correct, complete and timely information, they were six weeks ahead in one of the projects and were heading to be 1-2 weeks ahead of schedule in another project. Blay et al. (2019) identified less request for information (RFI) as a benefit of managing change. The interviewee no. 22 stated:

"It's removing the RFI...the wanted information it delays into. Every time somebody doesn't understand something, they have to request enough forms which causes delays. And they guess all this is money because of delays".

Managing common data environment (CDE) involves managing stakeholders. The information needs to be checked and approved for uploading to the CDE. In case the task team interface manager fails to resolve a clash between different parties, the lead designer needs to be involved. Therefore, generating and disseminating good quality information can reduce conflicts among stakeholders and contribute towards increasing efficiency.

\subsubsection{Cost, time and quality}

The interviewees agreed that managing stakeholders will eventually lead to cost savings 
$(83 \%)$, time savings (83\%) and improving the quality outcomes of a project $(70 \%)$.

They argued that by making stakeholders to collaborate in a BIM environment and using a CDE optimally will help in managing them. Consequently, it will reduce clashes onsite, assist in pre-planning and enhance information quality, which will eventually save time, cost, and improve quality. Related to cost savings by using BIM, interviewee no. 4 stated:

"The money that you're throwing away because of the mistakes, human mistakes, is going to get smaller and smaller."

Related to time savings and roller shutter door fitting in a BIM project, interviewee no. 7 noted:

"The fitters can pick up where the kitchen is. They can see the position of where the steel has to go. It's very quick for them to give us that design a lot earlier. Normally, those sorts of things would have to wait until you are further on in the project. So, it's accelerating everything.

Related to improving quality, interviewee no. 5 noted:

"So, they get a better product at the end of the day, a much better quality because you are not resolving things on-site in terms of so...this is client, end-user etc. and from our point of view as well because we are delivering better."

\subsubsection{Repeat business}

$78 \%$ of the interviewees (mostly main contractors as per Table II) agreed that getting repeat business is one of the biggest advantages of managing stakeholders, especially 
the client. Organisations bid for multiple projects in hope of winning one of these. It involves a huge amount of money to bid; therefore, if an organisation manages to set amicable relations with a private sector client, it increases their probability of working with the same client in the future through repeat business and thus avoiding the competition of a tendering process. Furthermore, it saves the money which would otherwise be spent on preparing for tendering. According to interviewee no. 17:

"There's a lot of repeat business that comes out in construction. If you do one good job with one client, you'd like to think that the next time that client has a project that you are going to be one of their front runners. And that's not just about delivering a highquality product at the end which obviously we want to do. We want to deliver-- if there are BIM requirements, there we need to make sure we deliver in the requirements that the clients asked for. Ultimately, we want to prove our reputation. So, we want potential repeat business with that client."

\subsubsection{Better understanding of the project workflow}

Interviewee no. 1, narrated a situation when they were working on a road project. They invited internal stakeholders including the client and external stakeholders such as police to show them the layout of traffic management signs that were to be set seven months after that meeting. This interviewee said that the BIM model made it easy for the stakeholders to understand the project. It facilitated exhaustive discussion. Due to this, they got tremendous feedback from the stakeholders. According to Interviewee no. 10: 
"So, effectively it means that you haven't got the discrepancies of one person thinking oh I thought this person thought they want a bat and is like no because BIM is trying to be as transparent as possible and as open as possible, people understand what everyone else is trying to achieve or are they trying to get, what it is that they need in terms of information.

Interviewee no. 20 narrated a situation of a road project which was passing alongside a golf course. Some trees of the golf course were required to be cut. The project team incorporated the golf course into the model and showed the owner how their golf course would look without those trees. The owner of the golf course appreciated that project team was considering the impact of the road on the golf course. It helped to win the trust of the owner, and they came to an agreement. Hence, understanding project workflow in a better way can improve relationship with the stakeholders. $74 \%$ of the interviewees corroborated this view.

\subsubsection{Better communication}

Communication is one of the key factors when it comes to stakeholder management. Good communication can avoid many issues from arising in the first place. Traditionally, the mode of electronic communication was mainly through emails and phone calls. The advent of BIM has changed that significantly. Most of the BIM software have the inbuilt capability to send messages to specific persons directly. The person to whom a message is sent gets a notification and can reply to the message directly. Automatic log is maintained of the communication which takes place. Blay et al. (2019) identified clarity in communication as a benefit of managing change on BIMimplemented projects. $70 \%$ of the interviewees agreed with this opinion. 
"In regard to things like advanced communication throughout the

BIM process, definitely there is enhanced communication between the consulting teams using models.” (Interviewee no. 16)

Interviewee no. 11 argued that the resulting benefits of a good communication are less waste, less cost and better quality; however, this same interviewee stated that it is difficult for new persons to get those benefits straightway. They have to become proficient in BIM.

Pertaining to the benefits of managing stakeholders, Chinyio and Akintoye (2008) mentioned 13 benefits of managing stakeholders in the context of the construction industry. This research identified some benefits discussed by Chinyio and Akintoye (2008), i.e., cost, time, anticipation of unforeseen problems and reduction in conflicts. The benefits identified in this research are considerably different from those mentioned in section 1 of this paper. The plausible explanation is that the empirical benefits identified in this study were focussed more specifically on BIM-implemented projects.

\section{Conclusions}

Adopting new technologies such as BIM, which radically change the existing modus operandi, is an evolution in construction and not a revolution. It may take years for an organisation to master a new technology fully. Organisations often face challenges from their stakeholders to make new working methods operate as a regular routine. This study aimed to explore and identify the key factors for managing stakeholders within BIM-implemented projects. Furthermore, the study sought to identify the diverse benefits of managing stakeholders.

'The learning experience' and 'the sharing and learning environment' were identified as enablers, whereas 'holding (face-to-face) meetings' and 'usage of online 
collaboration tools' were identified as key techniques of managing stakeholders on BIM projects. It is concluded that organisations should educate and train their staff. They should educate them so that project teams can learn what data they have to generate. Training should be provided on the implementation of software and about using common data environment. Organisations should provide enough time for their staff to learn to use and practise using IT systems.

Face-to-face interaction is preferred (wherever possible) over computermediated communication. Informal talk is preferred over sending emails on every issue. Organisations usually conduct meetings for discussing BIM models. These meetings help generate trust among project teams and each party can understand the expectations of the other party easily. At the outset of a project, meetings should be arranged among project participants for identifying the challenges they can encounter. Meetings should be arranged with the client to understand their requirements for the project and for them to explain their roles and responsibilities during the project.

Organisational learning should be promoted among the staff. This is because no one BIM tool can fit all types of projects. It is thus a constant learning process. Mentoring should be encouraged and supported by top management. This will create an amicable culture within a project, which will make it easy for less knowledgeable stakeholders to improve their knowledge and skills and will assist organisations which cannot afford educating and training their employees due to budget constraints. It will also assist in developing long-term relationships with smaller organisations.

Two types of benefits of managing stakeholders were identified: interim and ultimate. The interim benefits are clear understanding of the end result, unanticipated problems can be avoided, good quality information, better communication and better understanding of the project workflow can help in avoiding various types of conflicts 
from arising in the first place. Cumulatively, these interim achievements lead to the eventual benefits of improved cost savings, time savings, improved quality and repeat business.

Inadequate stakeholder management due to not using BIM can cause uncertainty and problems on a project which can lead to cost overruns, time delays, inadequate quality, less chances of working with those stakeholders again, unsatisfied stakeholders with the end results, and project managers may accomplish goals which were never intended by their stakeholders.

The empirical identification of techniques, enablers and benefits of managing stakeholders in the context of construction projects where BIM is used is the novelty of this research. This trio might have been investigated separately and in other sectors but combining them in a study in the construction context has not been done.

\section{Limitations and future work}

The research was limited to the UK construction industry. There is a huge scope of expanding it to other countries especially developing countries. The variables provided by this research can be investigated on a large scale by adopting a quantitative approach and using a questionnaire survey. The case study approach can also be adopted to further investigate this topic pertinent to a particular sector such as health or education. The research did not consider the teaching aspects of the subject matter, but its outcome, if adopted, can influence public policy. The outcomes of the research will also contribute towards updating the theory of the subject matters.

\section{Disclosure statement}

No potential conflict of interest was reported by the author(s). 


\section{References}

Ahuja, R., Sawhney, A., Jain, M., Arif, M. and Rakshit S. (2020), "Factors influencing BIM adoption in emerging markets - the case of India", International Journal of Construction Management, Vol. 20 No. 1, pp.65-76.

Akins, M.L., Griffin, J.R. (1999), “Keys to successful systems administration”, Computers in Library, Vol. 19 No. 3, pp.66-68.

Alreshidi, E., Mourshed, M., Rezgui, Y. (2017), "Factors for effective BIM governance”, Journal of Building Engineering, Vol. 10, pp.89-101.

Awwad, K.A., Shibani, A., Ghostin, M. (2020), "Exploring the critical success factors influencing BIM level 2 implementation in the UK construction industry: the case of SMEs", International Journal of Construction Management. DOI: $10.1080 / 15623599.2020 .1744213$

Blay, K.B., Tulli, M.M. and Mensah, J.F. (2019), "Managing change in BIM-level 2 projects; benefits, challenges and opportunities", Built Environment Project and Asset Management, Vol. 9 No.5, pp.581-596.

Cavanagh, S. (1997), "Content analysis: concepts, methods and applications", Nurse Researcher, Vol 4. No. 3, pp.5-16.

Chinyio, E.A., Akintoye, A. (2008), "Practical approaches for engaging stakeholders: findings from the UK", Construction Management and Economics, Vol. 26, No. 6, pp.591-599.

Chiu, W.Y.B. and Lai, J.H.K. (2020), "Building information modelling for building services engineering: benefits, barriers and conducive measures", Engineering, Construction and Architectural Management. DOI: https://doi.org/10.1108/ECAM-10-2018-0460

Comiskey, D., McKane, M., Jaffrey, A., Wilson, P. and Mordue, S. (2017), “An analysis of data sharing platforms in multidisciplinary education", Architecture Engineering and Design Management, Vol. 13 No. 4, pp.244-261.

Creswell, J.W. (2014), Research Design: Qualitative, Quantitative and Mixed Methods Approaches. $4^{\text {th }}$ ed. London: Sage.

Elo, S. and Kyngas, H. (2008), “The qualitative content analysis process”, Journal of Advanced Nursing, Vol 62. No. 1, pp.107-115.

Erlingsson, C. and Brysiewicz, P. (2017), "A hands-on guide to doing content analysis", African Journal of Emergency Medicine, Vol. 7, No. 3, pp.93-99. 
Etikan, I., Musa, S.A., Alkassim, R.S. (2016), “Comparison of Convenience Sampling and Purposive Sampling", American Journal of Theoretical and Applied Statistics, Vol. 5 No. 1, pp.1-4.

Ferreira, V.M, Ramos, F. (2014), "Promoting face to face communication through the use of a new micro-broadcasting Location Based-Service”, Procedia Technology, Vol. 16, pp.150-162.

Francis, J.J, Johnston, M., Robertson, C., Glidewell, L., Entwistle, V., Eccles, M.P, Grimshaw, J.M. (2010), "What is an adequate sample size? Operationalising data saturation for theory-based interview studies", Psychology and Health, Vol. 25 No. 10, pp.1229-1245.

Ghaffarianhoseini, A., Tookey, J., Ghaffarianhoseini, A., Naismith, N., Azhar, S., Efimova, O., Raahemifar, K. (2017), “Building Information Modelling (BIM) uptake: Clear benefits, understanding its implementation, risks and challenges", Renewable and Sustainable Energy Reviews, Vol. 75, pp.1046-1053.

Graneheim, U.H., Lundman, B. (2004), "Qualitative content analysis in nursing research: Concepts, procedures and measures to achieve trustworthiness", Nurse Education Today, Vol. 24 No. 2, pp.105-112.

He, Q., Wang, G., Luo, L., Shi, Q., Xie, J. and Meng, X. (2017), “Mapping the managerial areas of Building Information Modelling (BIM) using scientometric analysis”, International Journal of Project Management, Vol. 35, pp.670-685.

Huemann, M., Eskerod, P., Ringhofer, C. (2016), Rethink! Project Stakeholder Management. Pennsylvania: Project Management Institute.

Khoshfetrat, R., Sarvari, H., Chan, D.W.M., Rakhshanifar, M. (2020), “Critical risk factors for implementing building information modelling (BIM): a Delphi-based survey", International Journal of Construction Management. DOI: https://doi.org/10.1080/15623599.2020.1788759

Lee, J.Y.H. and Panteli, N. (2011), "You got email! The cases of inter-organizational collaboration for engineering product design", Engineering Management Journal, Vol. 23 No. 3, pp.18-21.

Lehtinen, J., Aaltonen, K., and Rajala, R. (2019), "Stakeholder management in complex product systems: Practices and rationales for engagement and disengagement", Industrial Marketing Management, Vol. 79, pp.58-70. DOI: 10.1016/j.indmarman.2018.08.011 
Lehtinen, J. and Aaltonen, K. (2020), “Organising external stakeholder engagement in inter-organizational projects: Opening the black box", International Journal of Project Management, Vol. 38, No. 2, pp.85-98.

Lindblad, H. and Vass, S. (2015), "BIM implementation and organisational change: A case study of a large Swedish public client", Procedia Economics and Finance, Vol. 21, pp.178-184.

Liu, Y., Nederveen, S.V. and Hertogh, M. (2017), "Understanding effects of BIM on collaborative design and construction: An empirical study in China”, International Journal of Project Management, Vol. 35, No. 4, pp.686-698. DOI: https://doi.org/10.1016/j.ijproman.2016.06.007

Marsh, P. (2017), "Structured mentoring in the engineering and construction sectors, Civil Engineering, Vol. 25 No. 5, pp.40-44.

Marshall, B., Cardon, P., Poddar, A. and Fontenot, R. (2013), "Does sample size matter in qualitative research? A review of qualitative interviews in IS research". Journal of Computer Information Systems, Vol. 54 No. 1, pp.11-22.

Masadeh, M. (2012), "Training, Education, Development and Learning: What is the difference"? European Scientific Journal, Vol. 8 No. 10, pp.62-68.

Mclntosh, M.J. and Morse, J.M. (2015), "Situating and Constructing Diversity in SemiStructured Interviews", Global Qualitative Nursing Research, pp.1-12. doi:10.1177/2333393615597674

Mellado, F. and Lou, E.C.W. (2020), "Building Information Modelling, lean and sustainability: An integration framework to promote performance improvements in the construction industry", Sustainable Cities and Society, Vol. 61, 102355.

NBS. 2015. National BIM Report [Accessed 10 October 2017]. Available at: https://www.thenbs.com/knowledge/nbs-national-bim-report-2015

Ograjensek, I. (2016), “Theory and Practice of Qualitative Research”, in Greenfield, T. and Greener, S. (Ed.s), Research Methods for Postgraduates. $3^{\text {rd }}$ ed. Chichester: John Wiley \& Sons; p.214-230.

Okakpu, A., Ghaffarianhoseini, A., Tookey, J., Haar, J., Ghaffarianhoseini, A. and Rehman, A.U. (2020), "Risk factors that influence adoption of Building Information Modelling (BIM) for refurbishment of complex building projects: stakeholders perceptions", International Journal of Construction Management. pp.1-13. DOI: https://doi.org/10.1080/15623599.2020.1795985 
Paul, R., Sharrard, J. and Xiong, S. (2016), "The importance of face to face communication in the digital world", Journal of Nutrition Education and Behaviour, Vol. 48 No. 10, pp.681. DOI: https://doi.org/10.1016/j.jneb.2016.09.014

Patton, M.Q. (2002), Qualitative Research \& Evaluation Methods. $3^{\text {rd }}$ ed. California: Sage.

Peansupap, V., Walker, D. (2005), "Factors enabling information and communication technology diffusion and actual implementation in construction organisations", Journal of Information Technology in Construction, Vol. 10, pp.193-218.

Robinson, O.C. (2014), "Sampling in Interview-Based Qualitative Research: A Theoretical and Practical Guide", Qualitative Research in Psychology, Vol. 11 No. 1, pp.25-41.

Schembri, J., Tang, Y.K., Fletcher, M. and Dimitratos, P. (2019), "How do European trade promotion organisations manage their stakeholders?" International Business Review, Vol. 2 No. 6, pp.1-10.

Schwandt, T.A. (2009), Dictionary of Qualitative Enquiry, Sage, London. Setia, M.S. (2016), "Methodology series module 5: Sampling strategies", Indian Journal of Dermatology, Vol. 61 No. 5, pp.505-509. [Assessed 30 August]. Available at: http://www.e-ijd.org/text.asp?2016/61/5/505/190118

Sheikhkhoshkar, M., Rahimian, F.P., Kaveh, M.H., Hosseini, M.R. and Edwards. D.J. (2019), "Automated planning of concrete joint layouts with 4D-BIM", Automation in Construction, Vol. 107, pp.1-13.

Singh, S., Chinyio, E. and Subashini, S. (2017), "The potential of BIM for stakeholder management in infrastructure projects", in Pathirage C., (Ed.s), 13th International Postgraduate Research Conference 2017, University of Salford, UK, p.552-563.

Tantalo, C. and Priem, R.L. (2016), "Value creation through stakeholder synergy", Strategic Management Journal. Vol. 37 No. 2, pp.314-329.

Turk, Z. (2020), "Interoperability in Construction - Mission Impossible?” Developments in the Built Environment. DOI: https://doi.org/10.1016/j.dibe.2020.100018. 
Vaismoradi, M., Turunen, H. and Bondas, T. (2013), "Content analysis and thematic analysis: Implications for conducting a qualitative descriptive study", Nursing and Health Sciences, Vol. 15, pp.398-405.

Wang, Y., Thangasamy, V.K., Hou, Z., Tiong, R.L.K. and Zhang, L. (2020), "Collaborative relationship discovery in BIM project deliver: A social network analysis approach", Automation in Construction, Vol. 114, pp.1-19.

Wembe, P.T. (2020), "Managing stakeholders in EPCM projects in Africa by Western project managers", International Journal of Construction Management. DOI: https://doi.org/10.1080/15623599.2020.1783599

Wembe, P.T. (2021), "Managing stakeholders in engineering procurement construction management projects in Africa by Chinese project managers", International Journal of Construction Management. DOI: https://doi.org/10.1080/15623599.2020.1868091

Yang, Y., Pan, M., Pan, W. (2019), “Co-evolution through interaction of innovative building technologies: The case of modular integrated construction and robotics", Automation in Construction, Vol. 107:102932. 